\title{
Practical Application of Technological Mineralogy on the Example of Studying of Sulphidization in the KMA Ferruginous Quartzites
}

\author{
S. Gzogyan ${ }^{(\bowtie)}$ and T. Gzogyan \\ Belgorod National Research University, Belgorod, Russia \\ mehanobrl@yandex.ru
}

\begin{abstract}
The results of mineralogical-petrographic researches of relationship of iron sulphidic minerals with a magnetite and their influence on the technological properties of the KMA ferruginous quartzites are presented. A classification of ferruginous quartzites by sulphidic factor on the basis of textural and structural features of the divided mineral components is developed.
\end{abstract}

Keywords: Ferruginous quartzites $\cdot$ Pyrite $\cdot$ Pyrrhotine $\cdot$ Magnetite $\cdot$

Sulphidic factor

\section{Introduction}

Actual problems of processing iron ores and quartzites remain increasing in the metallurgical value of the concentrate, reducing metal losses and costs in the production of commercial products. In increasing the efficiency of processing ferruginous quartzites a special role belongs to the scientific direction - the technological mineralogy. The transition from the descriptive methodology to the methodology of genetic analysis allowed giving a scientific interpretation of many problems associated with the technology of processing ferruginous quartzites.

\section{Methods and Approaches}

The object of a research is more than 900 group geological and technological samples of the KMA ferruginous quartzites obtained during the operational exploration of deposits, which reflect the most representative texture-structural and mineralogical features of the KMA quartzite deposits.

The study of the composition and properties of the samples taken was carried out using optical microscopy, NMR-spectroscopy, high-temperature magnetometry, microprobe analysis and X-ray diffractometry.

The physical properties are used to determine the microhardness of minerals and magnetic properties. The main attention is paid to relationship of iron oxides and sulphides and their distribution in the finished product. Researches were carried out on samples of polished sections and briquettes. 


\section{Results and Discussion}

The object of a research is more than 900 group geological and technological samples of the KMA ferruginous quartzites obtained during the operational exploration of deposits, which reflect the most representative texture-structural and mineralogical features of the KMA quartzite deposits.

The study of the composition and properties of the samples taken was carried out using optical microscopy, NMR-spectroscopy, high-temperature magnetometry, microprobe analysis and X-ray diffractometry.

The physical properties are used to determine the microhardness of minerals and magnetic properties. The main attention is paid to relationship of iron oxides and sulphides and their distribution in the finished product. Researches were carried out on samples of polished sections and briquettes.

The second category (medium enriched) includes ferruginous quartzites in which the structure of relationship between ore minerals and sulphidic minerals is more complex, that contributes to the transition to magnetite concentrate of both free grains of pyrrhotite and aggregates of magnetite with pyrite (Fig. 1b). From ferruginous quartzites of the second category (sulfur content 0.18 ), in the laboratory concentrate $0.09 \%$ remains (in the industrial one $-0.085 \%$ ).
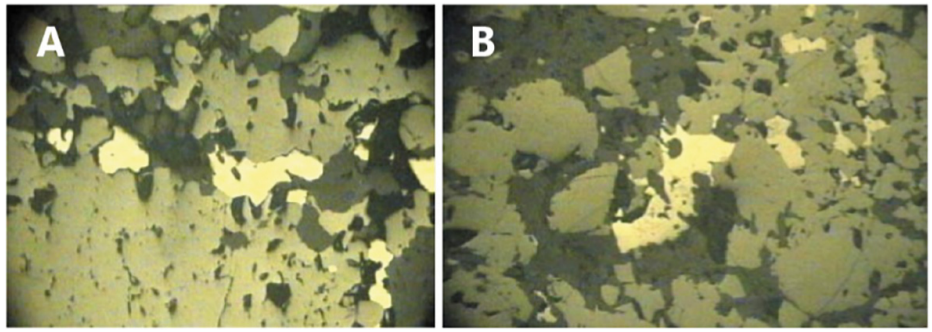

Fig. 1. Pyrite in magnetite aggregates (a) and internal and external intergrowths of pyrite with magnetite, poikilitic inclusions of pyrrhotite in magnetite (b), zoom $12.5 \times 8 \times 10$.

The third category of quartzites (hardly enriched) is represented by ferruginous quartzites with close structural intergrowths of sulphidic minerals with magnetite, poikilitic inclusions of pyrite in magnetite and pyrrhotite and vice versa, and that leads to the transition and concentration of sulphides in the process of wet magnetic separation into magnetite concentrate (Fig. 2).

With a total sulfur content in the feedstock of $0.42-0.47$ in the laboratory magnetite concentrate, its size reaches $0.42-0.78 \%$ (in the industrial one $-0.40-0.74 \%$ ).

Thus, optical and mineralogical researches have shown that clogging of magnetite concentrate with sulfur occurs not only because of the ferromagnetic properties of the monoclinic pyrrhotite variety, but also due to the inclusion of pyrite grains in the magnetite and pyrrhotite grains and vice versa (Table 1). 

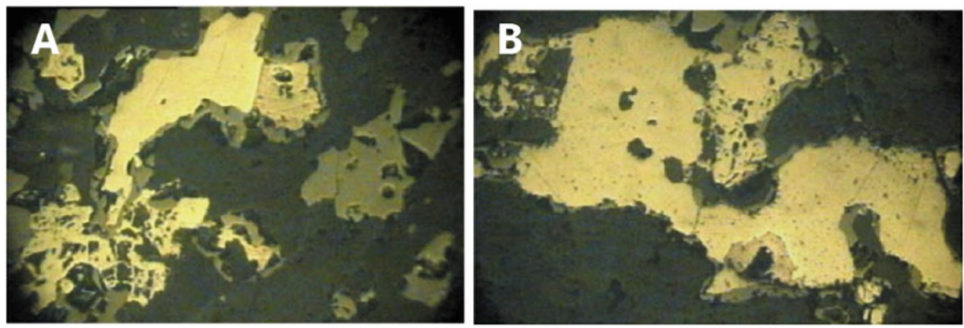

Fig. 2. Substitution structures of magnetite and pyrrhotite by pyrite, zoom $25 \times 8 \times 10$ (a), $12.5 \times 12.5 \times 10(\mathrm{~b})$.

Optical and mineralogical researches of finished products have established that sulphidic minerals in concentrate are as in the form of intergrowths and inclusions in magnetite grains as in the form of separate grains (Fig. 3).

Table 1. Grain composition and distribution of chemical components by grain size in the magnetite concentrate

\begin{tabular}{l|c|l|l|l|l}
\hline \multirow{2}{*}{ Grain size, $\mathrm{mm}$} & Yield of grain size, $\%$ & \multicolumn{4}{|l}{ Content, \% } \\
\cline { 3 - 6 } & & Fe & \multicolumn{2}{l}{$\mathrm{S}$} \\
\cline { 3 - 6 } & & Aggregate & Magnetite & Pyrite & Pyrrhotine \\
\hline+0.071 & 1.20 & 29.4 & 27.53 & 0.046 & 0.040 \\
\hline$-0.071+0.045$ & 4.20 & 55.29 & 33.37 & 0.024 & 0.018 \\
\hline$-0.045+0.032$ & 27.33 & 66.92 & 64.88 & 0.028 & 0.019 \\
\hline$-0.032+0.020$ & 45.03 & 71.05 & 66.55 & 0.023 & 0.016 \\
\hline-0.020 & 22.24 & 70.47 & 62.77 & 0.021 & 0.014 \\
\hline Total & 100.00 & 68.57 & 63.39 & 0.0242 & 0.0168 \\
\hline
\end{tabular}
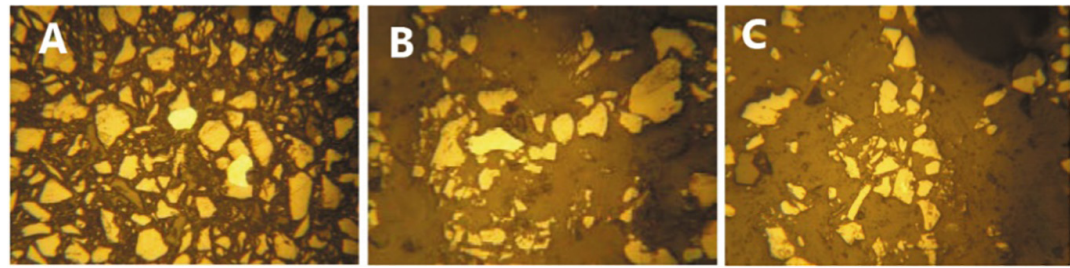

Fig. 3. Magnetite concentrate: aggregates of iron sulphides with magnetite and their separate grains (a, b) stand out against the background of free magnetite grains, poikilite inclusions in magnetite (c), polished briquette, zoom 132. 


\section{Conclusions}

Thus, applying the methods of technological mineralogy and based on the studied nature of the variability of structural transformations, the classification of quartzites was developed according to enrichment by the sulphidic factor.

The next important achievement of technological mineralogy in the context of a particular sulphidic problem is the clearly shown migration of non-magnetic iron sulphides into magnetite concentrate using magnetic separation processes.

Open Access This chapter is licensed under the terms of the Creative Commons Attribution 4.0 International License (http://creativecommons.org/licenses/by/4.0/), which permits use, sharing, adaptation, distribution and reproduction in any medium or format, as long as you give appropriate credit to the original author(s) and the source, provide a link to the Creative Commons license and indicate if changes were made.

The images or other third party material in this chapter are included in the chapter's Creative Commons license, unless indicated otherwise in a credit line to the material. If material is not included in the chapter's Creative Commons license and your intended use is not permitted by statutory regulation or exceeds the permitted use, you will need to obtain permission directly from the copyright holder.

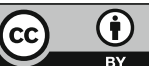

